When I first saved the file for this review, the Microsoft Word program asked me for a file name. Without giving it much thought, I typed in 'hope' and watched as my laptop started 'saving hope'. It struck me that the difficult but necessary operation of saving hope in the midst of globalising neoliberalism encapsulates what Ghassan Hage's Against Paranoid Nationalism is about. His ability to make theory accessible through clear, economical writing and an astute

\title{
saving hope
}

GHASSAN HAGE

Against Paranoid Nationalism: Searching for Hope in a Shrinking Society

Pluto Press Australia, Sydney, 2003

ISBN 0-85036-533-3

RRP \$29.95 (pb) grasp of and dexterity with the white Australian imaginary makes Against Paranoid Nationalism a deceptively slim volume: it is a book densely packed with ideas and possible applications for multidisciplinary researchers and teachers.

Hage has been tracing the racialised operation of Australian cultural and political discourse for some years now, and he by no means subscribes to the easy view that the transition from Paul Keating's to John Howard's Australia represents a radical rupture within white Australian subjectivity. It is just that with accelerating neoliberal economic and social reforms and the fundamentalist nationalism of John Howard things have become worse. Hage's previous Pluto publication, White Nation, identified a propensity for white people to 'worry' about the state of the nation; this latest book examines the development of a full-blown paranoia based in a sense of diminishing hope for society and the self.

Hage's work is extremely sensitive to the psychic and material investments that whiteness has in a place where the major impetus to federate as a nation-state was to keep nonwhites out and Indigenous people out of sight and mind. As many cultural commentators 
have observed, we are currently experiencing an uncanny return of this racialised order, with the incarceration of asylum seekers and attacks on Indigenous-rights agendas, the latter having previously appeared to have been boosted with the High Court's overturning of terra nullius in 1992. Hage observes that a decade of discourse against political correctness has shifted the definition of what constitutes a 'racist', so that 'hatred of the coloniser [is] the only real racism there is'. (x) To understand this development, he invokes Marx's camera-obscura theory of ideology to figure an upside-down picture of reality. I think many Keating-era academics, like myself, will relate to this when confronted, in classrooms, with white Australian (and American) students accusing Aboriginal activists and intellectuals of 'reverse racism' for staking their claims to Indigenous rights.

In Chapter 1, 'Transcendental Capital and the Roots of Paranoid Nationalism', Hage examines the phenomenon of 'compassion fatigue', whereby Australians who were once happy to extend 'the Good Life' to those coming from war-torn or poverty-stricken countries are now supporting the government's tough stance on and treatment of asylum seekers. Against this compassion fatigue stands a largely middle-class opposition that defies simple political categorisation as Right or Left and which is represented by churches and human-rights organisations. Their concern is that 'with the increased implementation of a dogmatic neo-liberal social and economic policy ... ethics and morality have been thrown out the window'. (8) Those constituting this group are condemned as naive, middle-class 'small "1" liberals' assuming the name of the 'ordinary people' by those that Hage describes as 'neo-tough conservatives'. While he finds it puzzling that the neo-toughs condemn the small 'l' liberals on this basis, considering that they also share the comforts of middle-class privilege, Hage does agree with them in one respect-many ordinary Australians have lost a sense of generosity:

Compassion, hospitality and the recognition of oppression are all about giving hope to marginalised people. But to be able to give hope one has to have it ... why is it that the great majority of the population of the Western world are left with so little hope for themselves today, let alone for sharing with others? (9)

Drawing on Bourdieu, he explains that societies are mechanisms for the distribution of hope. He distinguishes between hope against life, which takes the form of escapist fantasy, and hope for life, which enables us to 'invest ourselves in social reality'. To the extent we can invest ourselves in the fantasy of a national 'we', Hage argues that we are able to hope for 'the experience of the possibility of upward social mobility'. (13) In spite of the fact that capitalism actually tends to reproduce existing class locations, it is vital for their cohesion that capitalist societies make social mobility appear to be a fantasy that could come true for anyone. Hage explains that the way European societies have managed to distribute this belief is through a process of racialisation, which from the late-eighteenth century saw 'the increasing inclusion of nationally delineated peasants and 
lower classes into the circle of what each nation defined as its own version of civilised human society'. (15) Prior to this, the working classes were considered to be on the same level as 'primitive peoples', but afterwards 'skin color, in the form of European Whiteness, was emphasised, more than ever before as the most important basis for one's access to "dignity and hope"'. (15)

In the early twenty-first century, Hage argues, capitalism itself has increasingly taken a multinational form, and its investment in national societies is much more circumspect. With the growth of the financial and services sectors in particular, 'capitalism goes transcendental ... [I]t simply hovers over the Earth looking for a suitable place to land and invest ... until it is time to fly again'. (19) To attract this global capital, governments focus on making the nation attractive, promoting aestheticised global cities, which have:

no room for marginals ... As the state retreats from its commitment to the general welfare of the marginal and the poor, these people are increasingly—at bestleft to their own devices. At worst, they are actively portrayed as outside society. The criminalisation and labeling of ethnic cultures, where politicians and sections of the media encourage the general public to make a causal link between criminality, poverty and racial or ethnic identity, is one of the more unethical forms of such processes of exclusion. This is partly why globalisation has worked so well alongside the neo-liberal dismantling of the welfare state. The state's retreat from its commitment to seeing poverty as a socio-ethical problem goes hand in hand with its increasing criminalisation of poverty and deployment of penal sanctions. (20)

The reason for compassion fatigue becomes clear. Australians who used to experience the hope offered by society are feeling increasingly insecure but are living in a state of denial'hoping that their national identity will be a passport to hope for them'. (21) When these Australians see others also trying to access the hope of a better life, they become paranoid and vindictive, wanting to deprive asylum seekers and Indigenous Australians of the hope to which they are clinging only too tenuously.

In Chapter 2, 'On Worrying: The Lost Art of the Well-Administered National Cuddle', Hage draws on Spinoza and Kleinian psychoanalysis to illuminate the different conditions that produce 'worried' and 'hopeful' subjects. Spinoza's theory of the conatus as 'appetite for life' is connected to Kleinian theory, in which hope is 'linked to the internalisation of the good breast'. (24) The absence or unpredictable presence of the breast causes the infant to worry. In the case of the national subject, this worry is articulated through the question: 'Will my society care for me?' Hage goes on to examine the role of the 'cuddle' in the parent-child relationship. As opposed to the absence of physical affection or the suffocating bear hug, he argues that the 'well-administered cuddle':

manages to simultaneously embrace and protect and allow the child to contemplate 
the future and move towards what it has to offer ... It is precisely this kind of caring relation that national societies are ideally imagined to have with their members. Nation-states are supposed to be capable of providing a nurturing and caring environment and of having a considerable mastery in the art of border management ... Worriers cannot care about their nation because they have not been and are not being cared for properly by it. (29-30)

He concludes this discussion of paranoid nationalism with reference to the 'Children Overboard' case, asking:

What kind of people believe that a parent (even an animal parent, let alone a human being from another culture) could actually throw their children overboard? Perhaps only those who are unconsciously worried about being thrown overboard themselves by their own motherland? (30)

Chapter 3, 'Border dis/order: The Imaginary of Paranoid Nationalism', continues the focus on border protection by exploring the relationship between the 'motherland' and 'fatherland' in the national imaginary:

The fatherland's 'we' delineates first of all the we of the national will ensuring the motherliness of the interior ... [T] here is no contradiction between the 'order and border' politics of the fatherland and the loving and nurturing nature of the mother- land. Indeed the loving nurturing interior acquires its qualities because it is also a secure ordered place ... (37) The 'good father' of the national imaginary has to protect and secure the availability of the good breast of the motherland without undermining its 'goodness'. (39)

This gendered national imaginary generates a particular type of relationship towards 'the Others' that are projected outside the family of the 'we'. Using the psychoanalytic concept of 'avoidance', Hage argues that paranoid nationalists' sense of hope in the motherland's embrace is a fantasy that works to protect them from recognising that the good breast is actually being offered to 'Mr Transcendental Capital':

The national subject develops a pathological narcissism as s/he becomes unable to cope with the view of the other, as it risks puncturing his or her increasingly hollow 'hoped for motherland'. Here in Australia, nothing characterises this hollow fantasy as well as John Howard's hope of a traditional 1950s-style Australian society. (43)

In Chapter 4, 'A Brief History of White Colonial Paranoia', Hage addresses the historical specificities of Australian multiculturalism. $\mathrm{He}$ highlights four key points of tension between descriptive and prescriptive aspects of multiculturalism in Australia: multiculturalism as simple acceptance of cultural difference or its active promotion; multiculturalism as a mode of governing ethnic cultures or as the basis of a 
national identity; multiculturalism as welfare, coverage of September 11 and the Bankstown helping NESB migrants adapt to existing gang-rape trials saw Lebanese/Arabs/Muslims national institutions or as a socio-economic constructed as 'the new threat to Australia's policy designed to address structural inequali- Western civilisation ... a community of people ties produced around ethnicity; and multi- always predisposed towards crime, rape, illegal culturalism as a social policy aimed at affecting the life chances of migrants or as a form of cultural pluralism that enriches the nation as a whole through offering culturally diverse lifestyle possibilities. In conjunction with the High Court's Mabo decision and the economic uncertainties experienced by formerly securely middle-class white Australians, Hage argues, these tensions produced the conditions for a re-eruption of white paranoid nationalism. Reflecting on public media debate surrounding multiculturalism, he suggests:

It is as if what White paranoia is expressing is fear that the new multicultural order threatens the old assimilationist dream of an unquestionably European Australian culture, but given the censorship that now disallows use of such ethnocentric language, this fear is expressed in terms of the loss of any core culture. (66)

And this, in turn, works to prevent recognition of the paradox that '[the assimilationists] are the ones who have not assimilated to a changing society. This is exactly the closedcircuit logic that the White paranoid fantasy needs if it is to be able to reproduce itself.' (66) As a consequence 'Others' continue to be presented as a 'problem' about which the national subject must perpetually worry. Hence media entry to Australia and terrorism'. (68)

Chapter 5, 'The Rise of Australian Fundamentalism: Reflections on the Rule of Ayatollah Johnny', shifts from a focus on white paranoia about Muslim fundamentalism to examine John Howard's nationalist fundamentalism. Hage makes the provocative claim: 'There is nothing, logically speaking, that should stop us conceiving of a rational/bureaucratic/democratic politics as being animated by a fundamentalist ideology'. (70) After identifying a highly variegated set of values that the prime minister claims to be essentially Australian, such as 'the fair go', 'tolerance' and 'decency', Hage argues that it is the focus on essence itself that makes Howard a dangerous fundamentalist. He presents the government's dismissal of critical intellectuals as 'black arm-band' as a symptom of 'political narcissicism', and characterises the logic of Howard's fundamentalism as follows:

Detecting the Good essence becomes an exercise in emphasising the Good deeds of Australians and silencing those who want to emphasise the Bad deeds ... Thus any voice that attempts to insist that the misdeeds committed in Australia's past and present cannot be so easily dismissed is immediately considered a Bad voice ... one hell-bent on undermining the essential goodness of Australia and the pride of its 
people ... If someone emphasises racism, the response is that we have been essentially non-racist. If someone emphasises poverty, our response is that we have been essentially a class-free society. And as happened lately, if someone emphasises our bad treatment of refugee claimants, our response is that we have been essentially a welcoming country ... don't tell us we are bad-we are essentially good. Go and find someone really bad and tell them they are bad. (77)

He finishes this chapter by citing Philip Ruddock's threat to repeal the funding of a refugee-advocacy organisation critical of the government on the basis that 'We pay them to know better'. (78)

In Chapter 6, 'Polluting Memories: Migration and Colonial Responsibility in Australia', Hage addresses debates on national memory and responsibility for the past arising in response to the Mabo decision and the Bringing Them Home report into the stolen generations. He explores how white and other non-Indigenous Australians are respectively positioned in relation to the affects of shame and guilt generated through these debates. He highlights the inherently problematic use of the national 'we' in these discussions. With reference to Keating's famous Redfern speech, he argues that in the absence of an explicit recognition of a distinct Indigenous will (or sovereignty) white Australian projects of reconciliation are destined to 'be a momentary cover-up of the reality of the forces that made Australia what it is'. (94)
And this effectively makes 'the traumas of the colonisers ... the only "Australian" history someone assuming an Australian identity ought to face [and it continues] the process of marginalising the history of the colonised ... even at the very moment of expressing shame for colonisation'. (95)

Hage explores the implications of this persistent focus on the colonisers for migrant Australians' orientations towards their adoptive country's history. Arguing against suggestions that becoming Australian makes migrants complicit in colonial theft, he writes:

migrants have shared some important realities with Indigenous people too. Enduring the racist 'White Australia Policy', for example ... migrants are in a contradictory colonial location, and as such, they are quite capable of relating to Australia's history from within the imaginary 'we' of the colonised. Here, 'becoming responsible' is no longer guaranteed to mean contributing to the coloniser's postcolonial trauma-therapy that is oozing out of the 'coming to terms with the Australian past' discourse; it might just as well mean contributing to a struggle for Aboriginal sovereignty. (96)

The chapter concludes with an exploration of the ambivalent position of migrants in relation to the 'gift' of national identity. An anthropological observation of an exchange between youths at the Australian Arabic Communities Council's annual dinner highlights the fact that, 
for migrants, guilt about the unreciprocated gift of national life may be experienced in relation to the motherland from which the migrant comes, and is often mingled with resentment about the terms on which the host country offers the gift of stolen land.

Chapter 7, 'The Class Aesthetics of Global Multiculturalism', revisits themes addressed in chapters 1 and 4 and examines national governments' attempts to seduce transcendental capital through the promotion of aestheticised global cities. After demonstrating how middle classness mitigates some of the discriminatory effects of white racism, he argues that the acceptability and even desirability of middleclass professionals from every corner of the globe for various national governments continues to be underpinned by developmental racism, "primarily by aestheticising the self, which is itself achieved through a middle class image-based aestheticisation of the "group" one happens to belong to'. He argues further that, 'along with the class aestheticisation of the self comes the process of de-aestheticising the other, the one who is being racialised negatively'. (111-12)

Hage argues that these processes of aestheticisation and de-aestheticisation create essences such as 'Australian values' or, more recently, 'Asian values', which then become the ground of:

racist thinking, racist practices and racist institutions. It is because of this that there has been an increasing complicity between Asian developmental racism and global multiculturalism in highlighting images of the Asian as a spunky mediatic ideal, a classy investor, hardworking and clean-cut, and repressing the image of the workingclass or the underclass Asian. (115)

Having demonstrated the relationship between middle-class professionals and processes of self-aestheticisation, Hage poses a further question: 'Can migrants be racist?' He poses this question seriously-not simply to be provocative in the manner of neo-tough conservatives, who delight in performing the role of devil's advocate. And he probes further still: 'Why should the victims of racism be any more or less racist than the perpetrators? Why should they be seen as the repository of higher moral values?' (117) Two key points can be extracted from his investigation of this question: first, it is important to distinguish between groups that have the power to enact and institutionalise their racist fantasies and those who lack this power; second, the idea that only white people can be racist obscures the difference between the micro-spaces in which non-white racisms can occur (such as the local neighborhood or within a small businesses) and 'the macro Australian public/national space ... where Whiteness gives one most power to discriminate'. (118) Hage argues that both points needs to be addressed to prevent the emergence of a 'defensive multiculturalism which sees any critique of "one's ethnic community" as a threat'. (119)

I doubt I will be the only reader who found Chapter 8, 'Exghiophobia/Homiophobia: "Comes a Time We are all Enthusiasm", the most 
compelling chapter in the wake of September 11, the Bali bombings, the ongoing crisis of Israeli- Palestinian 'peace-processes' and, most recently, the invasion of Iraq. This chapter examines the relationship between exghiophobia - the fear of explanation - and homiophobia - the fear of the same. Hage reflects on why the intellectual attempt to rationalise the actions of suicide bombers is treated as a desire to justify or even exonerate them. In the context of the wars currently being waged on terrorism and illegal immigration by nations that see themselves as inheritors of 'Western civilisation', a social explanation is increasingly seen as an attempt to humanise essentially inhuman and inhumane Others. Hage distinguishes this antagonism towards humanising explanatory frameworks from xenophobia: 'what is really feared here is not the otherness of the other but their sameness'. (141-2)

The final chapter, 'A Concluding Fable: The Gift of Care, or the Ethics of Pedestrian Crossings', is based on an ethnographic account of Ali, a Lebanese factory worker and artist who migrated to Australia after his sister and niece were killed when their house was shelled, and following which he developed shell shock. A symptom of the shell shock, for which he was treated in Australia, was an obsession with pedestrian crossings. He loved the experience of all the cars stopping for him: 'It made me feel important! I thought it was magical!! Can you imagine this happening in Beirut?' (145) In being able to stop the traffic and in gaining treatment for his shell shock, Hage explains, Ali found his honour protected in Australia. He was able to receive the gift of social life from a society that extended care to him. 'As an Arab saying has it: the society that honours its members honours itself.' (149)

Hage contrasts the social ethics negotiated at the pedestrian crossing to the neoliberal concept of mutual obligation, which reduces:

the state's obligation to a delivery of services and empties it of all that is ethical: honour, recognition, community, sociality, humanity. The fact that we might give the unemployed some benefits but dishonour them in the very process of giving it to them, treat them as if they do not deserve what they are getting, as if they are a lesser breed of humanity, is immaterial to the neo-liberal economic mind that has colonised our governmental institutions: we've given, we want something back.

He links this neo-tough stance to a psychological theory, which argues that gifts consolidate a hierarchical power relationship between parents and children. Hage disputes the idea that the child is a passive recipient of the parental gift of life and sustenance by pointing to the very presence of the child as a gift to the parents. He brings this argument to bear on the relationship between nations and their citizens:

When I interact with others and I fail to receive from them the gift of the common humanity that we share, when I fail to see them as offering such a gift, it means that I 
consider such others as less than human. Here we have the basic unethical foundation of all forms of racism ... here we also have the unethical foundation of the policies of neo-liberal government. (151)

He offers the pedestrian crossing as a figure for an ethical sociality that neoliberal social and economic policies are destroying:

Today the Western world is dominated by governments that neglect to create the necessary pedestrian crossings that make our societies honorable civilised societies. They see it as unthinkable that the existing national cultures ought to yield before the marginalised forms of social inhabitance they constantly encounter. They treat the unemployed, the refugee, the Indigenous person as 'getting something for nothing', and in so doing fail to perceive in them the very humanity their presence brings. This negation of the marginal others that come our way becomes a negation of our very own humanity. (152)

The book concludes by returning the paranoid national subject to the colonial source of his/her pathology:

The pedestrian crossing is a social gift. It is also a piece of land; a piece of stolen land ... And until we choose to face and deal with the consequences of our colonial theft, it will remain the ultimate source of our debilitating paranoia. We will always 'worry about the nation' and will never fully know the joy of care. (152)

As a white Australian researcher and teacher, I found the experience of reading Against Paranoid Nationalism strangely therapeutic, in spite of my usual aversion to psychoanalytic approaches to social and cultural phenomena. It spoke particularly to my experience of teaching 'whiteness theory' to predominantly white Australian and American students who are often more traumatised by the revelation of their privilege than they are by horror stories of oppression and discrimination against 'Others'. I'm often at a loss to address the confusion and pain that the recognition of privilege provokes in my students-particularly in a context where they feel (and are) victimised by the pressures of ever-increasing HECS and student-loan debts. So I'm grateful to Hage for giving me a text to recommend to them that will not only help them to 'get over' the angst surrounding the recognition of their relative privilege but which will, more importantly, inspire them to participate in the urgent project of 'saving hope' against the global rampage of neoliberalism.

FIONA NICOLL Works in the Department of Gender Studies, University of Sydney, and the Centre for Cultural Research, University of Western Sydney. Her book From Diggers to Drag Queens was published by Pluto Press in 2001 and was short-listed for the NSW Premiers' Award. 